Article

\title{
Three Types of Denial: Think Tanks as a Reluctant Civil Society Elite
}

\author{
Katarzyna Jezierska \\ Division of Law, Politics and Economics, University West, S-461 32 Trollhättan, Sweden; E-Mail: katarzyna.jezierska@hv.se
}

Submitted: 13 March 2020 | Accepted: 10 June 2020 | Published: 4 September 2020

\begin{abstract}
Think tanks, or policy advice institutions, are civil society organizations producing and delivering social analysis to policymakers and the wider public. Their aim is to influence policy in a given direction. Compared to most other civil society organizations, they hold relatively privileged positions, both in terms of wealth (on average bigger budgets and staffs), political influence (their very raison d'être), knowledge (educational level of the staff), and social networks. Thus, it seems beyond dispute that think tanks adhere to the elite of civil society. This article focuses on think tanks' negative self-identification, on their reluctance to accept labels. Not only are think tanks unwilling to take on the elite designation, some of them also deny being part of civil society, and some go one step further in denying identification with the think tank community. These multiple denials are expected if we recall Pierre Bourdieu's observation that "all aristocracies define themselves as being beyond all definition" (Bourdieu, 1996, p. 316). The analysis focuses on how this definitional ambiguity is discursively constructed. Think-tankers are often described as situated in an interstitial space between such fields as politics, civil society, media, market, and academia. While this intermediary position is the source of their unique role as converters of various forms of capital, it also complicates the identity formation of think tanks. The argument is illustrated by Polish think tanks and the data consists of original interviews with think tank leaders. The article provides a novel perspective on think tanks and on civil society elites.
\end{abstract}

\section{Keywords}

Bourdieu; civil society; elite; Poland; think tanks

\section{Issue}

This article is part of the issue "Civil Society Elites" edited by Håkan Johansson (Lund University, Sweden) and Anders Uhlin (Lund University, Sweden).

(C) 2020 by the author; licensee Cogitatio (Lisbon, Portugal). This article is licensed under a Creative Commons Attribution 4.0 International License (CC BY).

\section{Introduction}

This article analyzes think tanks as a civil society elite. Think tanks, or policy advice institutions, are civil society organizations producing and delivering social analysis to policymakers and the wider public. Their aim is to influence policy in a given direction but one that, allegedly, is not defined by any vested interests. The claim to independence and orientation at influencing policymaking is central for think tanks (Jezierska \& Sörbom, 2020). The distinctive traits of think tanks are drawn from their interstitial position between other fields (Medvetz, 2012a, 2012b), such as academia, politics, media, market, and civil society. This in-between position leads to a combination of various qualifications, functions, and professional models in these organizations. Operating on the verge of other fields, think tanks perform boundary work converting capital from the other fields. Compared to most other civil society organizations, think tanks are relatively privileged, both in terms of wealth (on average bigger budgets), political influence (their very raison d'être), knowledge (educational level of the staff), and social networks. As such, it seems beyond dispute that think tanks belong to the elite of civil society.

This article focuses on the self-identification of think tanks. How do they identify with respect to the think tank community, the broader surrounding civil society, and their elite position in it? The argument is that think tanks, qua civil society elite, define themselves in negative terms. Their identity is built on three types of denial: of their place in civil society; of being a think tank; and of constituting an elite. While most think-tankers 
agree that, at least formally, they belong to civil society, they clearly mark their difference with respect to other civil society organizations. They also negate belonging to a civil society elite. Even more puzzling is that some think tanks decline the definition of their organization as a think tank. I argue that these denials are rather indicative of elites if we recall Pierre Bourdieu's observation that "all aristocracies define themselves as being beyond all definition" (Bourdieu, 1996, p. 316). This negative identification is interpreted as a logical consequence of think tanks' interstitial positioning between different fields, a source of their elevated status. Definitional ambiguity, even though frustrating for scholars of this phenomenon, actually suits these organizations well in the performance of their functions. To substantiate these claims, the article builds on interviews with Polish think-tankers. While studies of Polish civil society abound, it is still a rather understudied context for think tank scholarship.

The remaining text is structured as follows. First, I present a short reflection on the relation between civil society, think tanks, and elites, positioning this article in the Thematic Issue. Second comes a background section on the development of think tanks and civil society in Poland, followed by a brief clarification of which organizations were selected for this study and how they are analyzed. The analysis section is divided thematically in three types of denial. In the conclusion I try to make sense of the triple negative identification of think tanks.

\section{Does Civil Society Have Elites?}

Elites (from French élite, etymologically derived from Latin 'chosen, elected person') can be defined as those members of a society who hold socially privileged positions, whether in terms of wealth, political influence, cultural prestige, social networks, knowledge, or some other relevant assets, and who are recognized by others as legitimately occupying such a position (Bourdieu, 1996; Jezierski, 2020). In other words, elites constitute the hegemonic groups in a society. The notion of elite captures the relative position of various individuals and groups in a field. Any larger group will produce stratification, a hierarchical order with the privileged at the top (cf. iron law of oligarchy, Michels, 1915; Nodia, 2020). Thus, when we zoom in on the civil society field, we will necessarily discover differentiation between its members, with some cherishing a more elevated status.

Contrary to the usual approach of studying elites at the individual or group levels, the contribution of this article to the Thematic Issue is to interpret the theme of civil society elites as a distinction between various organizations of civil society. Instead of focusing on the elevated individuals within civil society, the article studies civil society organizations that, as organizations, have a higher standing. Seen this way, we necessarily bring the perspective of internal conflict and struggle to the analysis of civil society (cf. Gramsci, 1971/2005). The or- ganizations and individuals constituting civil society do not form a unified entity if there is social distinction and power at stake. Moreover, we should not expect any homogeneity or coherence among the elites. Those belonging to the elite (whether analyzed at the organizational or individual level) may well be dispersed and in conflict with each other. This is, in fact, what is more probable, as they compete for the same type of capital.

The argument in this article departs from the observation that think tanks are among the organizations that form the civil society elite. It is a common approach to analyze think tanks as part of civil society, as a specific type of NGO (e.g., Åberg, Einarsson, \& Reuter, 2019; Jezierska, 2018; McGann \& Weaver, 2000; Ohemeng, 2015; Stone, 2007). Civil society literature, on its part, often includes think tanks as an object of study (e.g., Diamond, 1994; Jobert \& Kohler-Koch, 2008; Scholte, 2002). However, an explicit discussion of what position think tanks occupy with respect to the broader civil society is rather rare (but see some comments about it in Jezierska, 2018; Klásková \& Císař, 2020; Stone, 2007). As Diane Stone (2007, p. 269) explains:

[T]hink tanks cater primarily to the economically and politically literate and are at some distance from the rest of society. The people who found these institutes and the people who work in them are usually highly educated, male, middle-class, Westernized professionals, often from privileged backgrounds. The organizational mandates-to inform and/or influence public policy-drives them to engage with other usually more powerful elites in society.

Hence, the contribution of this article is to bring this argument to the fore and analyze discursive means by which think tanks elevate themselves.

\section{Civil Society and Think Tanks in Poland}

For any study of civil society in Poland or other Central and Eastern European countries, the year 1989, which officially ended the state-socialist period (1945-1989), forms a critical juncture that cannot be ignored. It was a clear rupture in terms of political and economic organization of these societies, but also a spark for the construction of a new pluralistic public sphere. Obviously, 1989 was not a magical reset button (Iłowiecka-Tańska, 2011, p. 40), which forced all social life to organize anew. There is enough evidence of an "incomplete," "dissident," or "one-sided" civil society prior to 1989 (Buchowski, 1996; Ekiert \& Kubik, 2014), the Solidarity movement being just one prominent example. Nevertheless, the post1989 period undoubtedly offered substantially changed conditions and opportunities for civic action. Alongside the plethora of informal civic initiatives, a new organizational model materialized-the professionalized NGO. The mushrooming of these organizations added up to an "associational revolution" (Ekiert \& Kubik, 2014). Thus, 
the third sector, i.e., a legally recognized, institutionalized, and professionalized set of NGOs was a new phenomenon, while the wider civil society and civic engagement obviously had a longer tradition, stretching back to not only pre-1989 but also to before World War II (Frączak, 2013).

The formation of this new third sector in post-statesocialist Poland coincided with the emergence of think tanks. Most Polish think tanks were founded in the early years of transformation to liberal democracy and capitalism, i.e., in the 1990s and early 2000s. Just as in the case of civic engagement, one might identify proto-think tanks among organizations from the state-socialist period. However, given the conditions of policymaking under communist rule, these institutions were heavily controlled by the party and did not even aspire to make an appearance of independence. Since 1989, the pluralist model has been adopted in Poland (Czaputowicz \& Stasiak, 2012), allowing for non-governmental actors' engagement in policymaking. Just as Struyk (1999) reports in his study of Bulgaria, Armenia, Russia, and Hungary, in Poland too the support from Western governments and foundations for think tanks and NGOs more broadly was apparent from the first months of the transition. After the first wave of think tanks were launched in the early to mid-1990s their number oscillated at around 40 , which was in the top tier in the region. Among the more visible think tanks during that time were CASE-Center for Social and Economic Research (Centrum Analiz Społeczno-Ekonomicznych), founded in Warsaw in 1991, and Institute for Market Economy Research (Instytut Badań nad Gospodarkq Rynkowq), founded in Gdańsk in 1989. Both specialize in economic analysis and have been rather active in promoting the neoliberal orientation of reforms in Poland as well as in other Central European countries (cf. Krastev, 2000). Their successes were clearly shown by the hegemonic discourse of "no alternative" to the shock therapy style of transition (e.g., Ost, 2000; Woś, 2014). Another important institution from that early period is Batory Foundation (Fundacja Batorego) launched in Warsaw in 1988. Batory quickly became the go-to foundation supporting a variety of newly created NGOs in Poland and beyond. It also developed its own in-house social analysis unit, assisting transition to an open, liberal society, in line with the will of its founder, George Soros.

A second stage in the development of the Polish think tank landscape came around 2015, when the nationalist right-wing party Law and Justice (Prawo $i$ Sprawiedliwość) came to power, initiating a so-called second transition to 'illiberal democracy.' As of 2020, there are approximately 60 think tanks in the country. Many of the new organizations share the ruling party's ideological orientation and push it to promote conservative and Catholic policy solutions. The Institute for Legal Culture Ordo luris (Instytut na Rzecz Kultury Prawnej Ordo luris) is the prime example here. It was founded in 2013 and has been very active both in Poland and internation- ally (e.g., at the UN fora), proclaiming for instance antiabortion and anti-LGBT regulations.

In effect, the Polish think tank landscape is composed of quite varied institutions. Polish think tanks cover a broad ideological spectrum from the left to the right and they showcase diversity with respect to funding sources and size (Jezierska, in press). Compared to the more known cases from the Anglophone world, the actual involvement of Polish think tanks in policymaking is rather limited however (Biskup \& Schöll-Mazurek, 2018; Cadier \& Sus, 2017). There are surely some spectacular cases of successes in promoting given policy solutions, also by the above-mentioned think tanks, but on the whole, Polish think tanks lack systematic access channels to policymakers. Those who succeed need to be resourceful and find non-given paths to the ears of powerholders. Thinktankers usually blame their relatively meagre impact on the "immaturity" of the Polish political class (Jezierska, 2020), which results in policymakers only sporadically resorting to external policy advice. Nevertheless, think tanks have become given players on the Polish political scene and some of them manage to gain quite a lot of public attention.

In contrast to the vast literature on think tanks in the Anglophone world, especially in the US, the focus on think tanks in Central and Eastern Europe has so far attracted much less scholarly consideration. There is, however, a growing number of studies ranging from inventorial reports to more analytical approaches (on Central and Eastern Europe see e.g., Bigday, 2020; Jezierska \& Giusti, 2020; Keudel \& Carbou, 2020; Kimball, 2000; Klásková \& Císař, 2020; Krastev, 2000; Sandle, 2004; Schneider, 2002; Struyk, 1999; and specifically on Poland see Bąkowski \& Szlachetko, 2012; Biskup \& SchöllMazurek, 2018; Cadier \& Sus, 2017; Czaputowicz \& Stasiak, 2012; Hess, 2013; Jezierska, 2015, 2018, 2020a, 2020b; Zbieranek, 2011; Ziętara, 2010). This article builds on findings from this research and contributes the perspective on Polish think tanks as a civil society elite.

\section{Data and Methods}

There is no unequivocal definition of a think tank in the literature. The characteristics of think tanks most commonly pointed out are engagement in policy advice, independence from governments, and social interests such as firms, interest groups, and political parties as well as a non-profit character (e.g., Abelson, 2009; Rich, 2004; Stone, 2000; Weaver, 1989; Weaver \& McGann, 2000). All these attributes can be questioned in any given study of think tanks. Some think tanks are government institutions, some are party affiliated, other are sponsored by business organizations. Many institutions do conduct forprofit activities to diversify their funding and secure resources for the costly policy analysis. This makes think tanks a loosely defined organizational type. Following common praxis, this article departs from a working definition where think tanks are understood as civil soci- 
ety organizations that claim independence (but do not actually have to be independent) and attempt to influence policymaking (succeeding to varying degrees in this endeavor) based on the social analysis they produce. This definition is deliberately kept open to capture different declinations of the think tank model. Thus, the crucial aspects that helped identify the objects of this study are the research/analysis component in the organization, activities aiming at policy influence and claims to independence.

The selected sample of think tanks includes nine organizations (Batory Foundation, Civic Institute, Civil Development Forum, Ferdinand Lassalle Centre for Social Thought, Green Institute, Political Critique, Sobieski Institute, The Institute of Public Affairs, and The Unit for Social Innovation and Research-Shipyard) out of 40 existing at the time (2013). Hence, the data addresses the Polish think tank landscape at the end of its first stage of development (1989-2015), i.e., before the coming to power of the Law and Justice party. While the conditions for think tanks in Poland have changed after 2015, it is mostly visible in power shifts within the think tank community, with organizations previously marginalized now gaining traction because they support the ideological line of the ruling party and major organizations pre-2015 having problems with obtaining state-funded grants. It means that the analysis presented here, focusing on identification of think tanks as a specific type of organization, applies to the currently reconfigured space of think tanks as well.

All organizations selected for this study fulfill the working definition criteria and figure in previous literature as think tanks, even though, as we will see in the analysis, some deny identification with the think tank community. The sample was constructed to represent the Polish think tank population at the time. This means, for instance, that all but one of the studied organizations are located in the capital. To capture the diversity of the Polish think tanks, the sampled organizations vary in terms of ideological leaning (from the leftist Political Critique, the neoliberal Civil Development Forum, to the conservative Sobieski Institute), organizational age (e.g., Batory Foundation founded in 1988, Institute of Public Affairs founded in 1995, and Civil Institute founded in 2010), size of the budget and staff (e.g., Sobieski Institute with four employees and a budget below EUR 500,000, Institute of Public Affairs with 25 employees and a budget of almost EUR 2 million), as well as different areas of specialization (e.g., cultural policy for Political Critique, environmental policy for Green Institute, economic policy for Civil Development Forum, and a broad spectrum of policies for the Institute of Public Affairs).

It can be debated what constitutes the identity of an organization, whether it should be identified through how the leader defines the organization, or through the aggregated sense of identity of the staff. For the purpose of this article, I approach organizational identity through an interrogation of key figures in these organi- zations. Hence, the data consist of interviews with think tank leaders, i.e., those who have the power to strategically position the organization closer or further away from various surrounding actors (cf. van Knippenberg, 2016). In the case of bigger organizations, additional interviews were conducted with project leaders to capture a more comprehensive picture and make sure the individual identity narrative of the leader did not take over the organizational perspective. In total, 16 qualitative semi-structured interviews with Polish think tank leaders were conducted. Each interview lasted about an hour. In line with the informed consent, each conversation was recorded, transcribed, and translated to English by the author. It was made clear to the interviewees that they were expected to reflect upon their organization's position with regard to other fields, not their individual positioning.

The analysis of the data followed the standard procedure of qualitative content analysis (e.g., Mayring, 2004), with thematic coding of the interview material. The qualitative approach to data gathering and analysis has implications for the generalizability of the findings. While simple extrapolation to other contexts is not advised, it does not mean that the results presented here are purely idiosyncratic. Generalizability in qualitative research comes from the "fit of the topic or the comparability of the problem that is of concern" (Morse, 1999, p. 6). While the purposeful composition of the sample is obviously not representative in the statistical sense, it nevertheless captures the variety of positions that brings forth a comprehensive and credible identity narrative of Polish think tanks. Moreover, the issues related to the positioning of think tanks with regard to other civil society organizations and the specific intermediary role think tanks play is shared by this type of organization beyond Poland. Previous scholarship has convincingly argued that think tanks are best understood as boundary organizations (Medvetz, 2012b). This article analyzes what implications this intermediary position has for think tank identity and in this sense the results apply beyond the immediate case analyzed here. There are scattered comments in the literature indicating that this claim is substantiated. For instance, a study of Canadian think tanks (Lindquist, 1989) notes that thinktankers at times object to being classified as such. A recent article on Swedish and Polish think tanks (Jezierska \& Sörbom, 2020) singles out distancing from various actors, including civil society, as one fundamental mechanism by which these organizations wish to secure the perception of independence. The analysis in this article concentrates on one discursive strategy, i.e., denial, that I argue springs from the intermediary position of think tanks and helps them affirm their elevated position through distancing from other actors. The Polish case should be seen as an illustration of the specific arguments thinktankers use to maneuver their identity, putting forth specific denials of identification with civil society, with think tanks and with the elite. 


\section{Three Types of Denial}

\subsection{Denial 1: Not Civil Society}

In Poland, think tanks fall into the same legal category as other NGOs, thus being part of the third sector. Just like other NGOs, they register as either associations or foundations. However, the interviewed organizations display ambiguity with respect to a civil society identity. To mark their adherence to civil society, some of the interviewed think tanks use the label of 'think-and-do tank.' This is a way of stressing the activist component of what they do, combining advocacy and expert functions with direct community engagement (Jezierska, 2020). One thinktanker even argued that her organization is akin to a social movement: "Our aim was basically to combine the intellectual dimension with a social movement" (Political Critique). While this is a rather unusual claim, a recurring theme in the interviews was the desire to make a tangible impact on social life, by engaging in testing or implementing their proposed policy solutions. This positions the studied organisations in proximity to other NGOs:

[We] engage in social campaigning, realized in partnership with other organizations, which are NGOs but not think tanks. We subscribe to and feel like we are a part of this community. We don't want to be the know-it-alls who sit on the sidelines and say [what to do]. (Institute of Public Affairs)

Contrary to the perception of think tanks as distanced experts who deliver recommendations for action, here the drive to be active and connected to other NGOs was stressed. At the same time, think tanks' position with respect to the broader civil society is ambiguous. The interviewees recognize the formal categorization of their organizations as part of the third sector, even though their identity is often detached from it. The CEO of a leftist think tank clarifies:

The natural legal form of a think tank is an association, so in this way, I am part of the third sector. But I never had a need to work in the sector; what I wanted to do happened to be formally situated in the third sector. (Lassalle Centre for Social Thought)

The CEO from the conservative Sobieski Institute argues even more forcefully: "I don't see myself as a worker in the third sector. The third sector has connotations that I don't identify with." The distance to the third sector is emphasized and the distinctiveness of think tanks as professionalized knowledge producers and experts is highlighted. As the CEO from a major center-liberal think tank explains:

My dilemma was to choose an academic career or something else, so, frankly, I rather chose to work in a think tank than in the third sector.
So do you define it as something separate?

It wasn't obvious to me that I would work in the third sector. Think tanks were actually things that were slightly off to the side. (Institute of Public Affairs)

While the above quotes can be read as reflections about personal career trajectories, expressing the habitus of think tank leaders, they also reveal organizational identify. As the rich organizational literature has it, when it comes to identity the individual and organizational levels are closely intertwined (e.g., Dejordy \& Creed, 2016) and especially in the case of leaders, their perceptions of what a think tank is has huge impact on how they position the organization, its distance, or closeness to other actors.

Think tanks apparently have mixed identities and ambitions. Being "slightly off to the side," they both are and are not part of civil society. Denying a civil society identity is a way to carve their distinctive space in the sociopolitical landscape. What the interviewed organizations claim distinguishes think tanks from other NGOs are the intellectual ambition and research component of their activity, as well as the drive to engage in policymaking.

\subsection{Denial 2: Not Think Tanks}

As discussed above, the interviewed organizations ambiguously relate to the civil society field by stressing that their identity as think tanks takes priority. It might then seem slightly paradoxical that they, at times, also deny being think tanks. In the analyzed data, this second type of denial comes from two opposing positions. The interviewed organizations either pointed out their organizational deficiencies, which allegedly prevent them from living up to the think tank label, or conversely, they elevated themselves and dismissively talked about think tanks as organizations they do not want to be conflated with.

Not displaying a clear-cut think tank identity is explained by the necessity to engage in multiple tasks and not being able to keep the focus on what is perceived as the main think tank activity. This impurity of focus is mostly blamed on problems with securing stable funding over time:

As a pure think tank, it [the Institute of Public Affairs] would never survive, it wouldn't have enough financial means for the activities, so unfortunately, we need to reach out for different projects. We are careful to always have a research component, but it's often simply concrete engagement [konkretne działania]. (Institute of Public Affairs)

Here, again, the distinction between civil society and think tank functions is underscored and the very fact of mixing them is used to argue for an insufficiently pure think tank identity. The interviewees seem to believe that these problems are unique for the Polish context: 
Here [in Poland] it's very difficult to keep the [think tank] structure, and most of these organizations simply vegetate, taking on whatever they want or, rather, whatever they can. The Institute [of Public Affairs] also ended up there-"We do some training and some grant-giving because there was money for organizations dealing with legal help." The institutions become hybrids, not like in the West. (Batory Foundation)

While in other contexts funding might indeed be more readily available for think tanks (e.g., due to more developed philanthropy), hybridity is discussed in the academic literature as a typical feature of think tanks (e.g., Medvetz, 2012b; Stone, 2007). In the eyes of the interviewees, however, the impurity of focus on policy analysis and advice sets the Polish institutions apart, making them not fully think tanks. The dispute over what constitutes a think tank and how to identify one is apparently something the interviewees struggle with as well:

The hybrids emerge, like Shipyard and Political Critique [both interviewed for this study], with all their dissociating from being a think tank, they actually do, from time to time, put on the think tank hat. They also deal with policy issues; they aren't nonthink tanks. It's apparent that this clear-cut distinction is being erased. (Institute of Public Affairs)

As noted, impurity is partly blamed on financial instability. Most Polish think tanks rely on short-term public and private grants (Jezierska, in press), forcing them to take on varied tasks. Yet another factor that the interviewees list as seemingly disqualifying their organization as a think tank is insufficient academic credentials: "In fact, we couldn't compete with formal think tanks because we don't have this whole establishment with all the degrees" (Shipyard). Interestingly, we know from empirical findings from other contexts that even though conducting policy research is a necessary component of a think tank, it is present to a varying degree. To capture this variance in think tanks' dedication to research, only some organizations that have a significant number of academically accredited staffers and primarily produce academic-like book-length publications are dubbed "universities without students" (Weaver, 1989). For most think tanks, impurity of focus is a defining characteristic coming from their specific boundary position.

Some other interviewees stressed alterity with regard to the think tank identification aiming at positive distinction. Independence and the ambition of the interviewed organizations to initiate new debates were listed as elements that seemingly distance them from a think tank identity. Again, these qualities are usually included as core characteristics (or aspirations) of a think tank but were presented by these interviewees as something distinguishing their organization from, in this account, a negatively viewed 'real think tank':
That is, we for sure cherish more agency [podmiotowość] and feel more sovereign because think tanks are often linked to someone else, usually someone stands behind them. We have nobody behind us, and we're not anybody's instrument; this is how I'd put it. This is one thing, and another is the level of operating. Think tanks are more at the instrumental level, not truly creating completely new ideas but rather ascribing a certain ideology to given interests. (Political Critique)

Here, the perspective discussed above, in which a lack of identification with think tanks is explained by Polish institutions being insufficient in terms of their purity of focus, is reversed. What we see, in contrast, is a pejorative view of think tanks, while the interviewed organization conveys a more ambitious and independent image, looking down on think tanks and distancing itself from these institutions. In both cases, the denial is clear.

In a study of Canadian think tanks, Lindquist (1989) observes their reluctance to take on the think tank label noting several cases where respondents claim that they do more than 'think.' Apparently, particular motivations for denying a think tank identity might differ, but this type of denial seems to transcend the Polish case.

\subsection{Denial 3: Not Elite}

With regard to measures such as budget size (economic capital) and formal qualifications of the staff (educational capital), think tanks clearly place themselves in the upper tier of the civil society field. Despite some variation in budget sizes between Polish think tanks, the available assets of even the 'poorest' think tanks place them among the 'richest' NGOs in the country (cf. Jezierska, in press). According to a recent report (Klon/Jawor, 2019), in 2018 only $6 \%$ of all Polish NGOs operated with budgets bigger than EUR 230,000 (PLN 1 million), while all but two think tanks in this study exceed a EUR 500,000 budget. This is not surprising, given the fact that policy analysis and advice are expensive activities. They both require highly qualified staff and often long-term commitment to analysis on which policy recommendations are based. Higher education is generally correlated with engagement in civil society (Czapiński \& Panek, 2015), but even here think tanks stand out with respect to other NGOs, showcasing a higher level of academic credentials, which is the source of their expert image.

Apart from their main activities, i.e., attempts at directly or indirectly influencing policymakers based on the social analysis they produce, think tanks sometimes take an explicit leadership role with regard to the civil society in Poland. They often have "promotion of civil society" or "development of the public sphere" in their mission statements (Jezierska, 2018), thus positioning themselves as initiators or moderators of these entities. Think tanks also provide training, distribute funding, and offer other types of support for smaller NGOs. These functions 
might be read as an embracement of the civil society elite role.

However, rather than self-identifying as a civil society elite, think-tankers repeatedly stress their intermediary position between different elites. Having access to academia, civil society, media, and politics, they see themselves as enablers, mediators, or "vehicles of the articulation of elites...a machine to build social contact" (Sobieski Institute). They point to their function of connecting elites. Being partly associated with various fields, they accumulate and convert economic, academic and media capital into political capital using advocacy and networking as conversion tools (cf. Keudel \& Carbou, 2020). Thus, they become translators, brokers, or converters of the different forms of capital at stake in the surrounding fields. Their unique interstitial position allows think tanks to play the role of "mapping and gathering elites-people with knowledge, engagement, and contacts" (Sobieski Institute).

Asked about their target audience, the interviewees point to political, business, and media elites, the ones who decide the shape of a society. The role of think tanks, according to a leftist think tank, is to "put pressure on the political and economic elites to change their way of thinking" (Political Critique), which is the only way (progressive) social change can happen. Think tanks present themselves as crucial agents of change having enough organizational capacity and access to "people on important positions" (Sobieski Institute). They stress their interactions with elites, who are identified elsewhere.

With regard to budget size, formal qualifications of their staff and type of activity they perform (functions towards smaller organizations), Polish think tanks occupy a leading position with respect to Polish civil society. At the same time, they are also detached from civil society in the sense that they do not claim to represent a broader constituency, or any specific group in civil society. Their "assertion of a voice in the policy-making process is based on their claim to expertise rather than as a vox populi" (Weaver \& McGann, 2000, p. 17). Think tanks claim to serve ideas, not members or followers (or funders), which creates distance between them and other NGOs. "NGOs may therefore view the 'research community' negatively: elite, exclusive and with insubstantial connections to the general public" (Stone, 2007, p. 270). Think tanks are closely tied with other elites and are viewed by others as an elite, but they do not themselves identify as constituting an elite. Instead, they see their role as putting pressure on elites, mediating between different elite types and converting various forms of capital. It should be noted that the usually pejorative descriptions of elitism and elitist (Williams, 2015) obviously influence any groups' propensity to self-identify as an elite.

\section{Conclusion}

This article focused on the self-identification of Polish think tanks. A comprehensive study of elites should in- clude both the self-perceptions and means adopted to gain the privileged status as well as legitimation procedures, i.e., processes through which other groups and individuals in the field legitimize and counter the elevated position of the elite (Jezierski, 2020). The latter, however, is left for future studies to explore. The argument in this article, investigating self-identification only, is not that all Polish think tanks express all three types of denial. Some of them do, while others stress one of the types and perceive the other identifications as less problematic. Nevertheless, seen collectively, as the space of think tanks, the ambiguous positioning with respect to other fields emerges as an important characteristic of think tanks. This ambiguity is also reflected in the lack of definitional clarity in the academic literature on think tanks. There is no widely accepted definition of think tanks and scholars often resort to working definitions to make empirical studies feasible.

What unites all think tanks is their interstitial position. They occupy the space in-between the fields of politics, media, academia, and civil society. Such a position grants them the role of intermediaries-being the ones who understand and to some extent incorporate the logics of all those fields, they are not engaged in one field only. As intermediaries, think tanks convert different types of capital, becoming translators or brokers. Their elevated position is not based on the number of members or followers, but rather on the capacity to formulate policy recommendations or discourse around a policy issue in such a way that it gets traction among decision makers and/or the broader public. This is facilitated through a think tank's academic credentials-which give them the image of experts - through their fluency in the media language which allows them to formulate their recommendations as soundbites, through their links to civil society which makes these recommendations appear as disinterested and non-for-profit, and through their contacts in policy circles-which grant them access to those who make political decisions. The interstitial position, however, is both the very key to think tanks' unique role and what complicates their (self-)identification. To grasp who they are and to carve out a sufficiently distinctive identity multiple points of reference are needed. The Polish example provides an illustration of what the intermediary role of think tanks entails for their identity with denial of identification with various fields as a discursive strategy to deal with the interstitial position. Based on sporadic comments from previous literature, we can infer that this is not a unique trait and strategy for Polish think tanks. However, more studies on other contexts are needed, also to verify whether the specific arguments used by Polish think tanks are unique.

This article analyzed three types of denial, which I contend are central to a think tank identity. The studied Polish think tanks deny their identification with civil society, with the think tank community and with being a (civil society) elite. If we follow Bourdieu (1996), claims to being "beyond all definition" are indicative of elites. 
Although some recognition and visibility are needed to attract funders, to some extent think tanks also need to stay obscure, which helps them exert policy influence without attracting too much attention and calls for accountability. The rhetorical moves of denial can also be seen as an expression of what Cynthia Weber (2016) calls a "plural figure" that defies categorization as either/or. Weber (2016) sought to describe a pluralized masculine and/or feminine identification. In the case of think tanks, plurality refers to identifications with roles, functions, and logics of the multiple fields in which think tanks are immersed, while defying any simple ascription to a single field.

\section{Acknowledgments}

It is funny how the study of medieval societies conducted by my life partner, Wojtek Jezierski, keeps intersecting with my own research on modern times. For these and all other unexpected intersections I am truly grateful.

\section{Conflict of Interests}

The author declares no conflict of interests.

\section{References}

Abelson, D. E. (2009). Do think tanks matter? Assessing the impact of public policy institutes. Montreal: McGill-Queen's University Press.

Åberg, P., Einarsson, S., \& Reuter, M. (2019). Think tanks: New organizational actors in a changing Swedish civil society. Voluntas. Advance online publication.

Bąkowski, T., \& Szlachetko, J. H. (Eds.). (2012). Zagadnienie think tanków $w$ ujęciu interdyscyplinarnym [Think tanks in an interdisciplinary perspective]. Gdansk: Wydawnictwo Uniwersytetu Gdańskiego.

Bigday, M. (2020). Genesis of a social space: Think tanks in Belarus 1992-1995. East European Politics and Societies. Advance online publication.

Biskup, B., \& Schöll-Mazurek, K. (2018). Instytucjonalne podstawy doradztwa politycznego oraz lobbingu w polsko-niemieckim porównaniu [The institutional basis of political advice and lobbying in a comparison between Poland and Germany]. In A. Kopka, D. Piontek, \& M. Minkenberg (Eds.), Doradztwo polityczne i lobbing w parlamentarnym procesie decyzyjnym: Polska i Niemcy w perspektywie porównawczej [Political advice and lobbying in the parliamentary process: Poland and Germany in a comparative perspective] (pp. 157-198). Krakow and Nowy Targ: Wydawnictwo ToC.

Bourdieu, P. (1996). The state nobility: Elite schools in the field of power. Stanford, CA: Stanford University Press.

Buchowski, M. (1996). The shifting meanings of civil and civic society in Poland. In C. Hann \& E. Dunn (Eds.), Civil society: Challenging Western models (pp. 79-98). London: Routledge.
Cadier, D., \& Sus, M. (2017). Think tank involvement in foreign policymaking in the Czech Republic and Poland. The International Spectator, 52(1), 116-131.

Czapiński, J., \& Panek, T. (Eds.). (2015). Diagnoza społeczna [Social diagnosis]. Warsaw: Rada Monitoringu Społecznego. Retrieved from http://www. diagnoza.com/pliki/raporty/Diagnoza_raport_ 2015.pdf

Czaputowicz, J., \& Stasiak, D. (2012). Political expertise in Poland in the field of foreign policy and the emergence of think tanks. In S. Brooks, D. Stasiak, \& T. Zyro (Eds.), Policy expertise in contemporary democracies (pp. 165-182). Farnham: Ashgate.

Dejordy, R., \& Creed, D. W. E. (2016). Institutional pluralism, inhabitants, and the construction of organizational and personal identities. In M. G. Pratt, M. Schultz, B. E. Ashforth, \& D. Ravasi (Eds.), The Oxford handbook of organizational identity (pp. 374-395). Oxford: Oxford University Press.

Diamond, L. (1994). Rethinking civil society: Toward democratic consolidation. Journal of Democracy, 5(3), 4-17.

Ekiert, G., \& Kubik, J. (2014). The legacies of 1989: Myths and realities of civil society. Journal of Democracy, 25(1), 46-58.

Frączak, P. (2013). W poszukiwaniu tradycji: Dwa dwudziestolecia pozarzqdowych inspiracji [Searching for a tradition: Nongovernmental inspirations from the interwar period and the last two decades]. Warsaw: OFOP.

Gramsci, A. (2005). Selections from the prison notebooks. New York, NY: International Publishers. (Original work published 1971)

Hess, A. (2013). Polskie think tanki jako społeczni uczestnicy dyskursu politycznego [Polish think tanks as the social participants of political discourse]. Athenaeum: Polskie Studia Politologiczne, 37, 37-57.

Iłowiecka-Tańska, I. (2011). Liderzy i działacze: O idei trzeciego sektora $w$ Polsce [Leaders and activists: On the idea of the third sector in Poland]. Warsaw: Wydawnictwa Uniwersytetu Warszawskiego.

Jezierska, K. (2015). Moral blueprint or neoliberal gobbledygook? Civil society frames among Polish think tanks. East European Politics and Societies, 29(4), 831-849.

Jezierska, K. (2018). Performing independence: The apolitical image of Polish think tanks. Europe-Asia Studies, 70(3), 345-364.

Jezierska, K. (2020). Dangling in a vacuum. A presentation of Polish think tanks in political life. East European Politics and Societies. Advance online publication.

Jezierska, K. (in press). Pecunia olet: The funding dilemma for think tanks in Poland. In L. Kings, Z. Kravchenko, \& K. Jezierska (Eds.), Resourceful civil society? Adaptation, negotiation and contestation of the reconfigured civil society space. London: Palgrave Macmillan.

Jezierska, K., \& Giusti, S. (2020). Introduction: Travelling 
from west to east. Think tank model adaptation to Central and Eastern Europe. East European Politics and Societies. Advance online publication.

Jezierska, K., \& Sörbom, A. (2020). Proximity and distance: Think tanks handling the independence paradox. Governance. Advance online publication.

Jezierski, W. (2020). Introduction: Nordic elites in transformation, c. 1050-1250: Legitimacy and glory. In W. Jezierski, K. Esmark, H. J. Orning, \& J. V. Sigurðsson (Eds.), Nordic elites in transformation, c. 1050-1250 Vol. III: Legitimacy and glory (pp. 1-35). New York, NY: Routledge.

Jobert, B., \& Kohler-Koch, B. (Eds.). (2008). Changing images of civil society: From protest to governance. London: Routledge.

Keudel, O., \& Carbou, O. (2020). Think tanks in a limited access order: The case of Ukraine. East European Politics and Societies. Advance online publication.

Kimball, J. D. (2000). From dependency to the market: The uncertain future for think-tanks in Central and Eastern Europe. In J. G. McGann \& K. R. Weaver (Eds.), Think tanks and civil societies: Catalysts for ideas and action (pp. 251-272). London and New Brunswick, NJ: Transaction Publishers.

Klásková, M., \& Císař, O. (2020). Agents of Europeanization: Think tanks discussing the refugee crisis in the Czech Republic. East European Politics and Societies. Advance online publication.

Klon/Jawor. (2019). Raport: Kondycja organizacji pozarzqdowych 2018 [Report: The condition of nongovernmental organizations 2018]. Warsaw: Stowarzyszenie Klon/Jawor. Retrieved from https://api.ngo.pl/media/get/108904

Krastev, I. (2000). The liberal estate: Reflections on the politics of think tanks in Central and Eastern Europe. In J. G. McGann \& K. R. Weaver (Eds.), Think tanks and civil societies: Catalysts for ideas and action (pp. 273-292). London and New Brunswick, NJ: Transaction Publishers.

Lindquist, E. (1989). Behind the myth of think tanks: The organization and relevance of Canadian think tanks (Unpublished Doctoral dissertation). University of California, Berkeley, CA, USA.

Mayring, P. (2004). Qualitative content analysis. In U. Flick, E. von Kardorff, \& I. Steinke (Eds.), A companion to qualitative research (pp. 266-269). London: SAGE.

McGann, J. G., \& Weaver, K. R. (Eds.). (2000). Think tanks and civil societies: Catalysts for ideas and action. London and New Brunswick, NJ: Transaction Publishers.

Medvetz, T. (2012a). Murky power: 'Think tanks' as boundary organizations. In D. Courpasson, D. Golsorkhi, \& J. J. Sallaz (Eds.), Rethinking forms of power in organizations, institutions, and markets (pp. 113-134). Bradford: Emerald.

Medvetz, T. (2012b). Think tanks in America. London and Chicago, IL: University of Chicago Press.

Michels, R. (1915). Political parties: A sociological study of the oligarchical tendencies of modern democracy.
New York, NY: The Free Press.

Morse, J. M. (1999). Qualitative generalizability. Qualitative Health Research, 9(1), 5-6.

Nodia, G. (2020). Democracy's inevitable elites. Journal of Democracy, 31(1), 75-87.

Ohemeng, F. L. K. (2015). Civil society and policy making in developing countries: Assessing the impact of think tanks on policy outcomes in Ghana. Journal of Asian and African Studies, 50(6), 667-682.

Ost, D. (2000). Illusory corporatism in Eastern Europe: Neoliberal tripartism and postcommunist class identities. Politics and Society, 28(4), 503-530.

Rich, A. (2004). Think tanks, public policy, and the politics of expertise. Cambridge: Cambridge University Press.

Sandle, M. (2004). Think tanks, post-communism and democracy in Russia and Central and Eastern Europe. In D. Stone \& A. Denham (Eds.), Think tank traditions: Policy research and the politics of ideas (pp. 121-140). Manchester and New York, NY: Manchester University Press.

Schneider, J. (2002). Think-tanks in Visegrad countries: From policy research to advocacy. Budapest: Centre for Policy Studies.

Scholte, J. (2002). Civil society and democracy in global governance. Global Governance, 8(3), 281-304.

Stone, D. (2007). Recycling bins, garbage cans or think tanks? Three myths regarding policy analysis institutes. Public Administration, 85, 259-278.

Stone, D. (Ed.). (2000). Banking on knowledge: The genesis of the global development network. London: Routledge.

Struyk, R. J. (1999). Reconstructive critics: Think tanks in post-Soviet bloc democracies. Washington, DC: Urban Institute Press.

van Knippenberg, D. (2016). Making sense of who we are: Leadership and organizational identity. In M. G. Pratt, M. Schultz, B. E. Ashforth, \& D. Ravasi (Eds.), The Oxford handbook of organizational identity (pp. 335-350). Oxford: Oxford University Press.

Weaver, K. R. (1989). The changing world of think tanks. Political Science and Politics, 2(3), 563-578.

Weaver, K., \& McGann, J. G. (2000). Think tanks and civil societies in a time of change. In J. G. McGann \& K. Weaver (Eds.), Think tanks and civil societies: Catalysts for ideas and action. London and New Brunswick, NJ: Transaction Publishers.

Weber, C. (2016). Queer international relations: Sovereignty, sexuality and the will to knowledge. New York, NY: Oxford University Press.

Williams, R. (2015). Keywords: A vocabulary of culture and society. Oxford: Oxford University Press.

Woś, R. (2014). Dziecięca choroba liberalizmu [The infantile disorder of liberalism]. Warsaw: Wydawnictwo Studio Emka.

Zbieranek, P. (2011). Polski model organizacji typu think tank [The Polish model of the think tank organization]. Warsaw: Wydawnictwo Naukowe Scholar. 
Ziętara, W. (2010). Think tanks na przykładzie USA $i$ Polski [Think tanks in case of the USA and
Poland]. Lublin: Wydawnictwo Uniwersytetu Marii Curie-Skłodowskiej.

\section{About the Author}

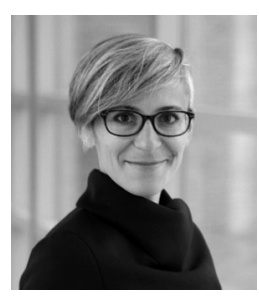

Katarzyna Jezierska is Associate Professor in Political Science and Senior Lecturer at the International Programme in Politics and Economics, University West, Sweden. She is also Researcher in the Gender and Diplomacy Program at Gothenburg University, Sweden. Jezierska's research is situated in the broader fields of political sociology and democratic theory. She has published on civil society, political advice, radical democracy, and diplomacy. Her publications from 2020 can be found in Governance, East European Politics and Societies, The Hague Journal of Diplomacy, as well as in Routledge and Palgrave MacMillan. 